\title{
Some chewing lice (Phthiraptera) species as ectoparasites infested aquatic birds with a new record of three species from Al-Sanaf marsh/ southern Iraq
}

\author{
Z.A. Mohammad \\ Department of Biology, College of Education for Pure Science, University of Thi-Qar, Thi-Qar, Iraq \\ Email: zainababdalimohammad@yahoo.com
}

(Received May 26, 2019; Accepted July 6, 2019)

\begin{abstract}
The present study was carried out to determine additional chewing lice of aquatic birds and additional data on the prevalence of chewing lice in aquatic birds found on the Southern marshes of Iraq. Sixty-nine of different species of aquatic birds were randomly collected and examined for chewing lice in Al-Sanaf marsh, which is located in Thi-Qar province / Southern Iraq, between October 2016 and February 2017, the lice placed in tubes containing 70\% ethanol after that they cleared, mounted and identified according to morphological features. Twenty-five (36.23\%) out of 69 aquatic birds were infested with chewing lice, a total of six lice species were identified from birds in the current study included Piagetiella titan and Pectinopygus forficulatus infested White Pelican Pelecanus onocrotalus, Actornithophilus piceus lari infested Slender-billed Gull Larus geni, Actornithophilus himantopi infested Black-Winged stilt Himantopus himantopus, Rallicola fulicae isolated from coot Fulica atra and Rallicola parani infested moorhen Gallinula chloropus. Three lice species: Pectinopygus forficulatus, Rallicola fulicae and Rallicola parani were recorded in current study for the first time in Iraq. We need further investigations of Phthiraptera fauna are very important, not only to complete the list, but also to provide information about parasite-host vector relationships and phylogenetic relation among species.
\end{abstract}

Keywords: Chewing lice, Aquatic birds, Al-Sanaf marsh, Southern Iraq Available online at http://www.vetmedmosul.com, (C) 2020, College of Veterinary Medicine, University of Mosul. This is an open access article under the CC BY 4.0 license (http://creativecommons.org/licenses/by/4.0/).

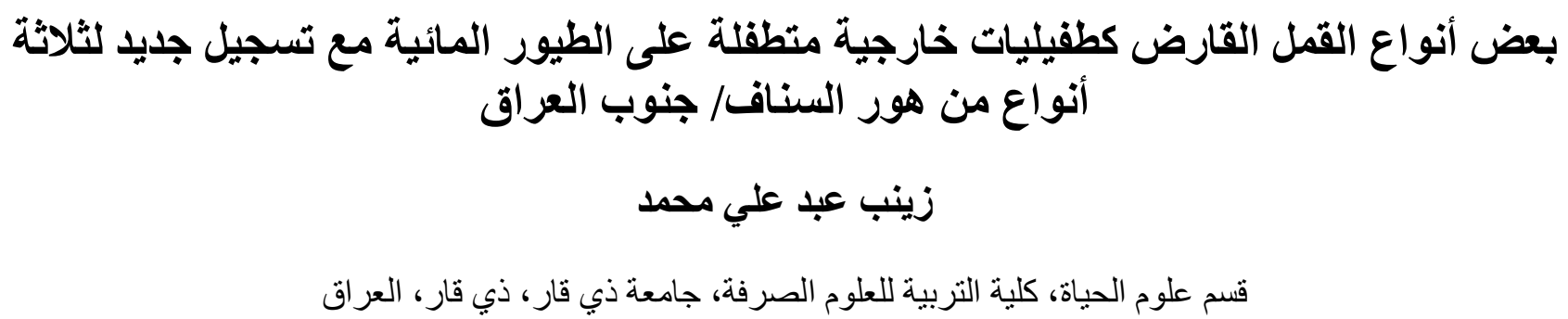

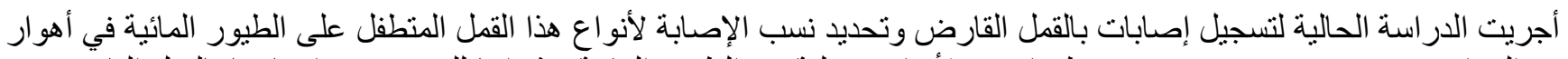

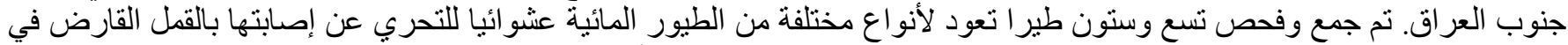

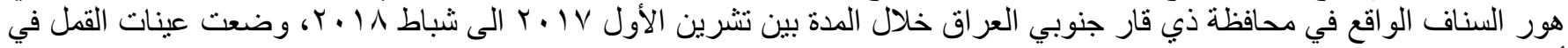

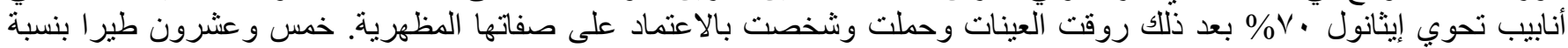

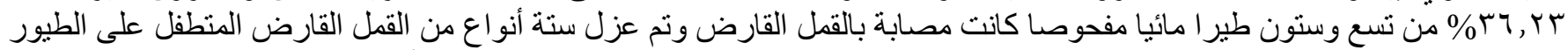
في الدراسة الحالية والذي تضمن Pectinopygus forficulatus و Piagetiella titan من البجع الأبيض Actornithophilus و Slender-billed Gull Larus genei من النورس مستدق المنقار Actornithophilus piceus larig onocrotalus

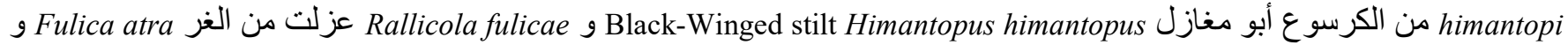




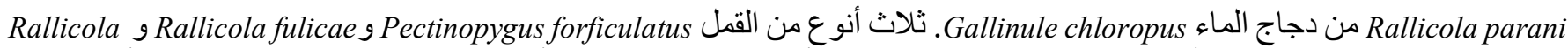
إن parani

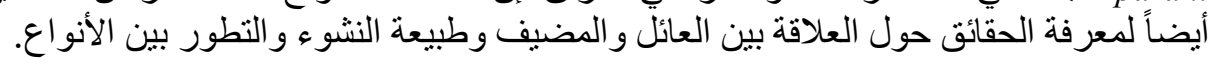

\section{Introduction}

Chewing lice are small wingless insects, that are found as ectoparasites on birds and mammals, they are characterized by their chewing mouth parts (1), and they are permanent obligate ectoparasites feed on feathers and skin scales and cause skin irritation and suck blood, causing decrease in productivity of the host (2), as they deteriorate the quality of the plumage, provoke small holes on feathers, and increase feather breakage (3). Four thousand lice species were recorded on avian species in the world (4), most studies of chewing lice of birds in Iraq were concerned with chewing lice infested domesticated birds as chickens and pigeons $(5,6,7)$. The studies about chewing lice of aquatic birds are very limited. The chewing lice fauna of aquatic birds is almost unknown in Al-Sanaf marsh which located in the western north part of Al-Hammar marsh eastern south of Thi-Qar province /southern Iraq its area is nearly $250 \mathrm{Km}^{2}$, it is used by many aquatic birds such as fish eating-birds, some new records for the aquatic bird louse fauna have been recorded in recent years $(8-10)$.

The present study was carried out to document additional chewing lice of aquatic birds and determination the prevalence of chewing lice in aquatic birds found on the southern marshes of Iraq.

\section{Materials and methods}

A total of 69 aquatic birds belonging to five bird species white pelican $P$. onocrotalus, slender-billed gull L. genei, black-winged stilt $H$. himantopus, $\operatorname{coot} F$. atra and moorhen G. chloropus were randomly collected from Al-Sanaf marsh southern Thi-Qar province were examined for the chewing lice infestation. The feathers of each birds were carefully examined, then the birds were placed in nylon bags contain chloroform in cotton pieces for 15 minutes. Then in the laboratory the lice collected and preserved in $70 \%$ ethanol, cleared in $10 \% \mathrm{KOH}$ and washed with distilled water, passed in alcohol series 70, 80, 90 and $99 \%$, mounted on slides in Canada balsam and examined by light microscope (2). The infestation percentage and mean of intensity (11).

Infestation percentage $=$ (number of infested birds / number of examined birds) x 100

Mean of intensity $=$ (number of isolated parasites / number of infested birds)
The identification of the lice species was carried out according to (12-18). The identification of some lice specimens was confirmed by Bilal Dik from Division of Parasitology, Selcuk University, Konya, Turkey. The parasites measured by using light microscope with divided ocular lens and all measurements done in millimeter

\section{Results}

Five aquatic bird species were collected from Al-Sanaf marsh and examined, these birds related to three orders and four families (Table 1).

Six different chewing lice species were identified from five aquatic birds: $P$. titan and $P$. forficulatus on white pelican $P$. onocrotalus, A. piceus lari on slender-billed gull L. geni, A. himantopi on black-winged stilt $H$. himantopus, $R$. fulicae on $\operatorname{coot} F$. atra and $R$. parani infested moorhen $G$. chloropus. Three lice species $P$. forficulatus, $R$. fulicae and $R$. parani were recorded in the current study for the first time in Iraq (Table 2).

\section{Piagetiella titan}

This lice species was isolated from white pelican $P$. onocrotalus (Figure 1).

\section{Pectinopygus forficulatus}

This lice species was isolated from white pelican $P$. onocrotalus with prevalence $100 \%$ and mean of intensity 53.50 (Figure 2).

The measurements of five males were total body length (3.32-3.54) $3.46 \mathrm{~mm}$, head length (0.66 -0.69) $0.67 \mathrm{~mm}$, head width (0.54-0.58) $0.56 \mathrm{~mm}$, thorax length (0.61-0.67) 0.65 $\mathrm{mm}$, thorax width $(0.54-0.64) 0.59 \mathrm{~mm}$, abdomen length (2.23-2.60) $2.33 \mathrm{~mm}$, abdomen width (0.71-0.84) $0.80 \mathrm{~mm}$.

\section{Actornithophilus piceus lari}

This lice species was isolated from slender-billed gull $L$. genei with prevalence $13.33 \%$ and mean of intensity 2.00 (Figure 3).

\section{Actornithophilus himantopi}

This lice species was isolated from black-winged stilt $H$. himantopus with prevalence $6.66 \%$ and mean of intensity 1.00 (Figure 4). 
Table 1: Species of examined aquatic birds for chewing lice in the current study

\begin{tabular}{llll}
\hline Order & Family & Common name of bird & Scientific name of bird \\
\hline Pelecaniformes & Pelecanidae & White Pelican & P. onocrotalus \\
Charadriiformes & Laridae & Slender-billed Gull & L. genei \\
\multirow{2}{*}{ Ralliformes } & Recurvirostridae & Black-Winged stilt & H. himantopus \\
& Rallidae & Coot & F. atra \\
\hline
\end{tabular}

Table 2: Aquatic bird species studied, infestation percentage and lice species

\begin{tabular}{lccccc}
\hline Aquatic bird species & $\begin{array}{c}\text { No. of examined } \\
\text { birds }\end{array}$ & $\begin{array}{c}\text { No. of infested } \\
\text { birds }\end{array}$ & $\%$ & $\begin{array}{c}\text { Lice } \\
\text { species }\end{array}$ & $\begin{array}{c}\text { Mean of } \\
\text { intensity }\end{array}$ \\
\hline White Pelican $P$. onocrotalus & 2 & 2 & - & P. forficulatus* & - \\
Slender-billed Gull L. genei & 15 & 2 & 13.33 & A. piceus lari & 2.00 \\
Black-Winged stilt H. himantopus & 15 & 1 & 6.66 & A. himantopi & 1.00 \\
Coot $F$. atra & 12 & 7 & 58.33 & R. fulicae* & 19.50 \\
Moorhen G. chloropus & 25 & 13 & 52.00 & R. parani* & 14.00 \\
\hline Total & 69 & 25 & 36.23 & & \\
\hline
\end{tabular}

* First record in Iraq.
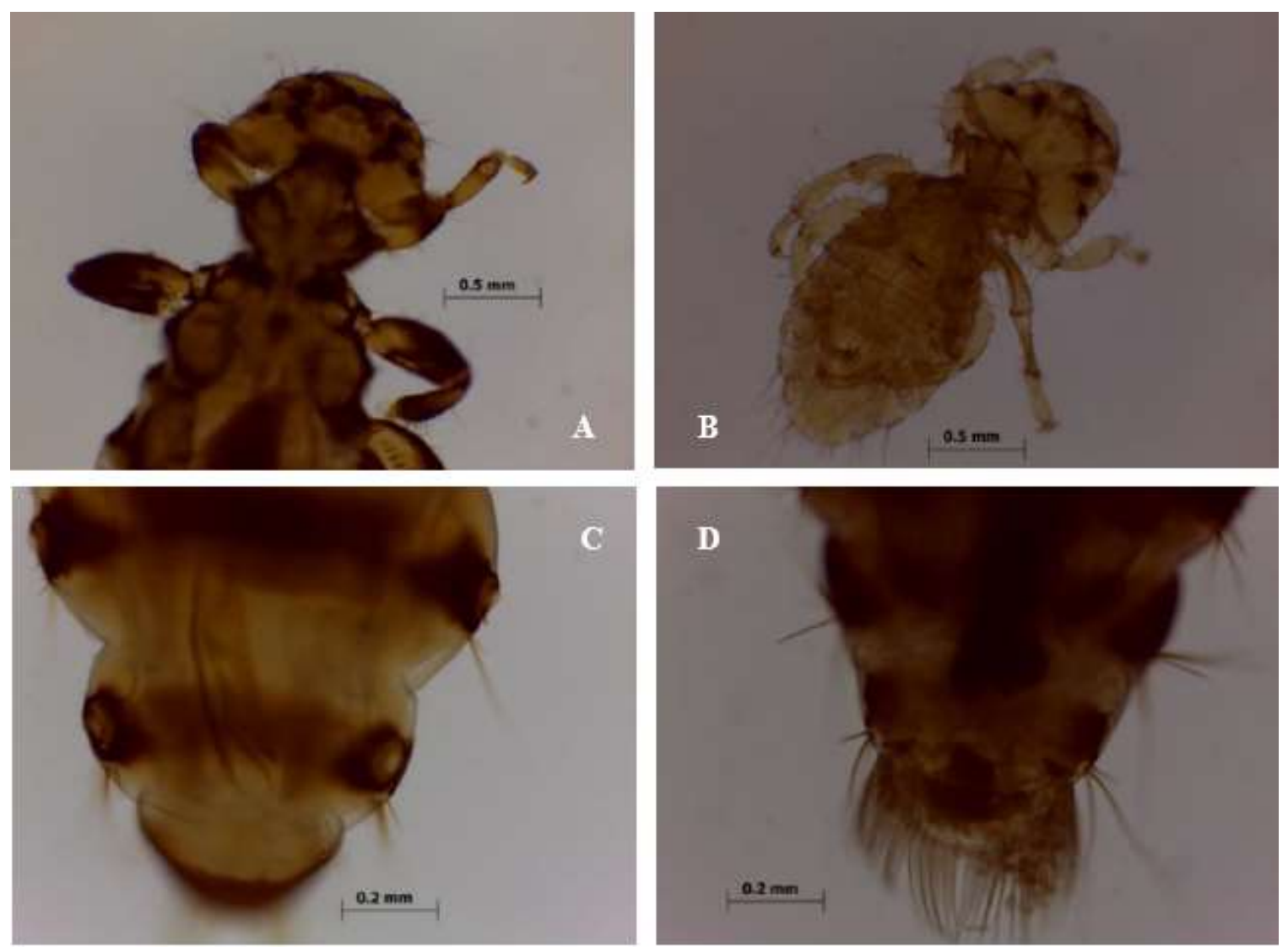

Figure 1: (A) Piagetiella titan lice showed anterior end, 40x. (B) larvae, 40x. (C) adult male posterior end, 100x. (D) adult female posterior end, 100x. 

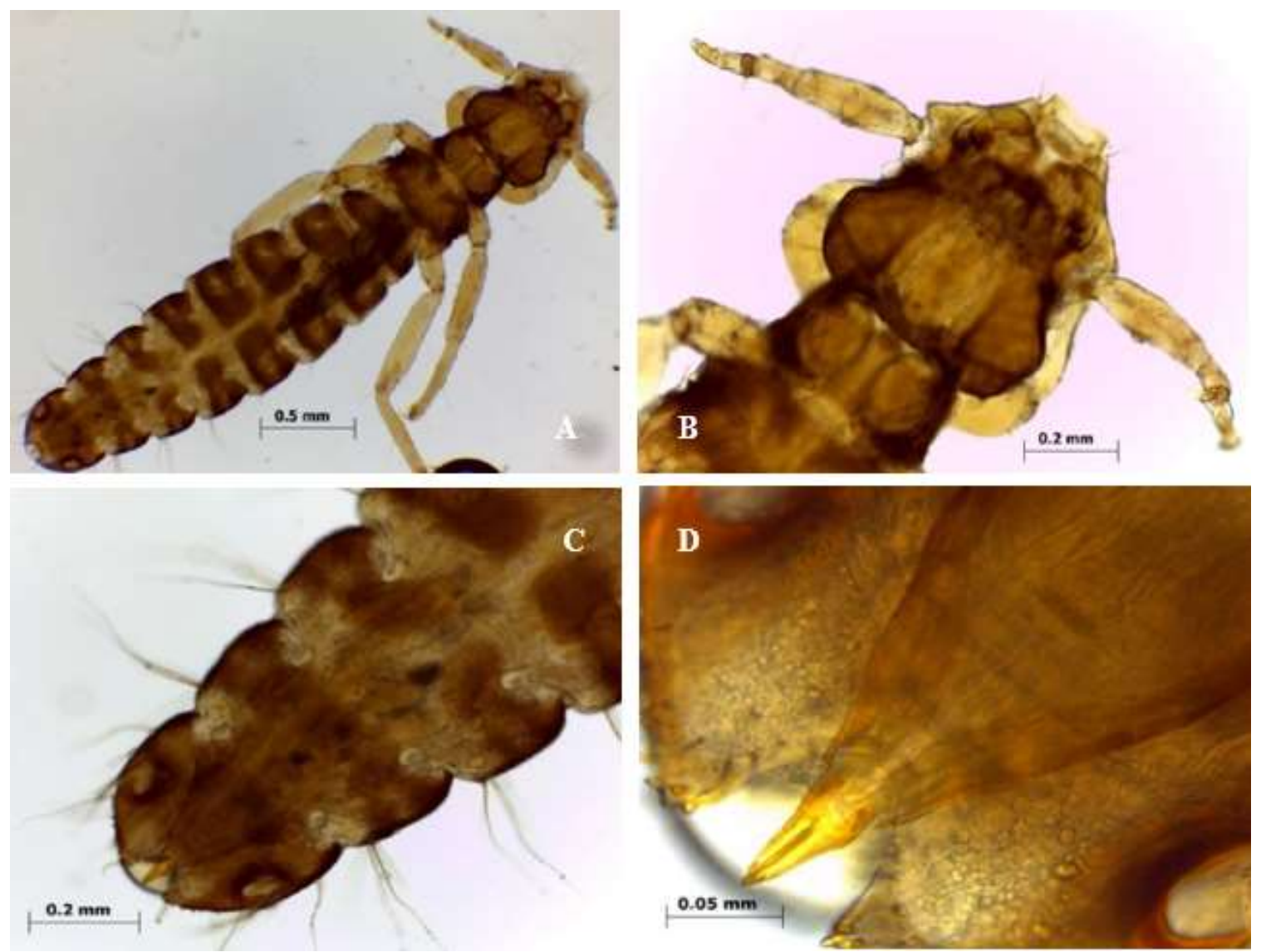

Figure 2: (A) Pectinopygus forficulatus lice showed adult male, 40x. (B) anterior end, 100x. (C) adult male posterior end, 100x. (D) male genitalia, 400x.

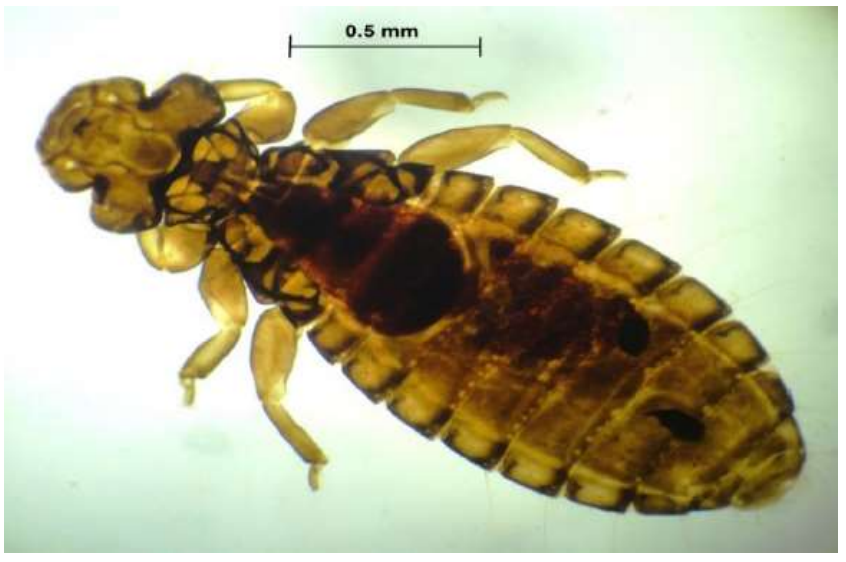

Figure 3: Actornithophilus piceus lari showed adult female, 40x.

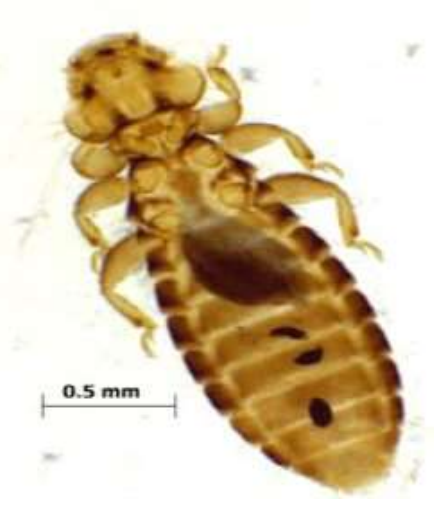

Figure 4: Actornithophilus himantopi showed adult female, 40x. 


\section{Rallicola fulicae}

This lice species infested $F$. atra with prevalence $58.33 \%$ and mean of intensity 19.50 (Figure 5).

The measurements of five males were total body length (1.07-1.25) $1.21 \mathrm{~mm}$, head length (0.39-0.49) $0.43 \mathrm{~mm}$, head width (0.31-0.39) $0.33 \mathrm{~mm}$, thorax length $(0.20-0.23) 0.21$ $\mathrm{mm}$, thorax width $(0.29-0.33) 0.32 \mathrm{~mm}$, abdomen length (0.53-0.62) $0.61 \mathrm{~mm}$, abdomen width (0.31-0.45) $0.41 \mathrm{~mm}$. The measurements of five females were total body length (1.13-1.27) $1.25 \mathrm{~mm}$, head length (0.40-0.47) $0.42 \mathrm{~mm}$, head width $(0.35-0.40) 0.41 \mathrm{~mm}$, thorax length $(0.21-0.29) 0.27$ $\mathrm{mm}$, thorax width $(0.30-0.34) 0.32 \mathrm{~mm}$, abdomen length (0.65-0.70) $0.68 \mathrm{~mm}$, abdomen width (0.45-0.52) $0.50 \mathrm{~mm}$.
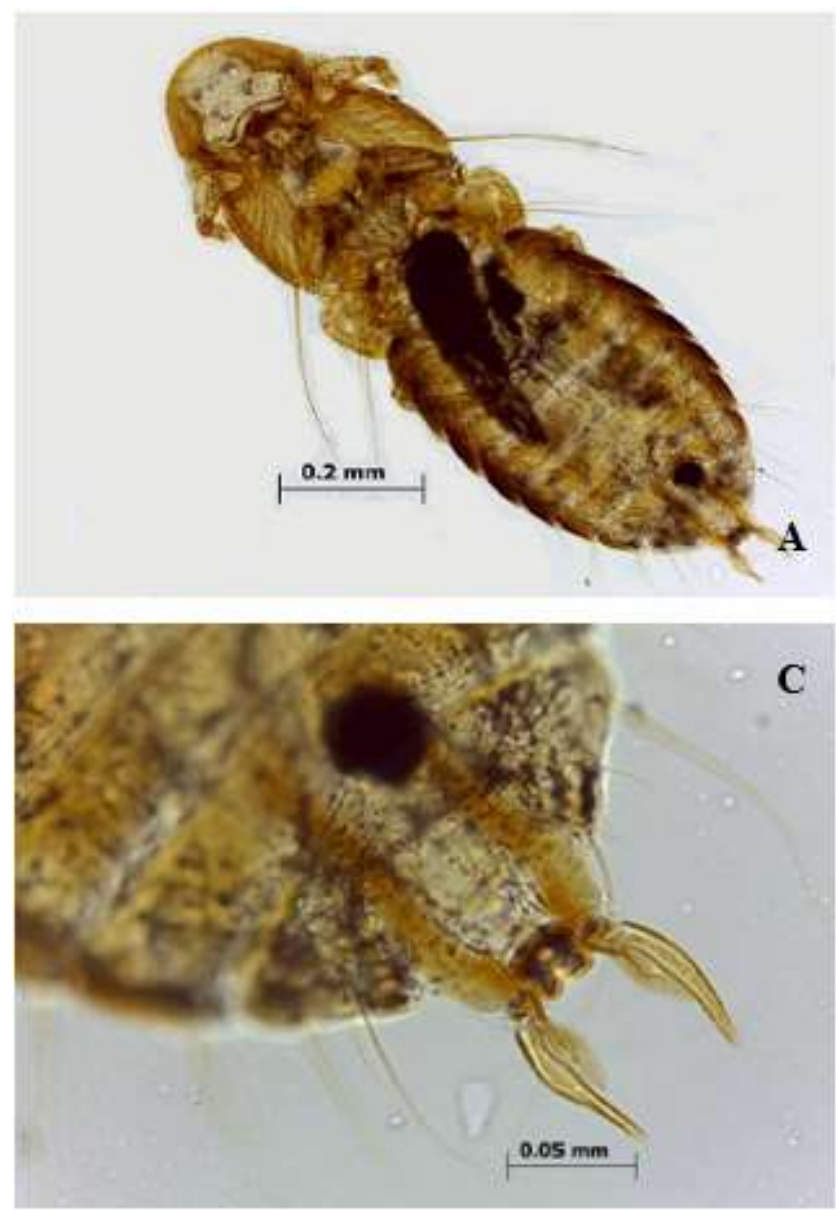

\section{Rallicola parani}

This species of Rallicola genus infested G. chloropus with prevalence $52.00 \%$ and mean of intensity 14.00 (Figure $6)$.

The measurements of five males were total body length (1.53-1.64) $1.61 \mathrm{~mm}$, head length (0.40-0.45) $0.44 \mathrm{~mm}$, head width (0.31-0.36) $0.34 \mathrm{~mm}$, thorax length $(0.23-0.28) 0.26$ $\mathrm{mm}$, thorax width $(0.31-0.34) 0.32 \mathrm{~mm}$, abdomen length (0.89-0.95) $0.94 \mathrm{~mm}$, abdomen width (0.45-0.50) $0.48 \mathrm{~mm}$. The measurements of five females were total body length (1.51-1.58) $1.56 \mathrm{~mm}$, head length (0.41-0.47) $0.44 \mathrm{~mm}$, head width (0.36-0.40) $0.38 \mathrm{~mm}$, thorax length (0.22-0.29) 0.27 $\mathrm{mm}$, thorax width $(0.30-0.35) 0.33 \mathrm{~mm}$, abdomen length (0.90-0.96) $0.95 \mathrm{~mm}$, abdomen width (0.46-0.52) $0.50 \mathrm{~mm}$.
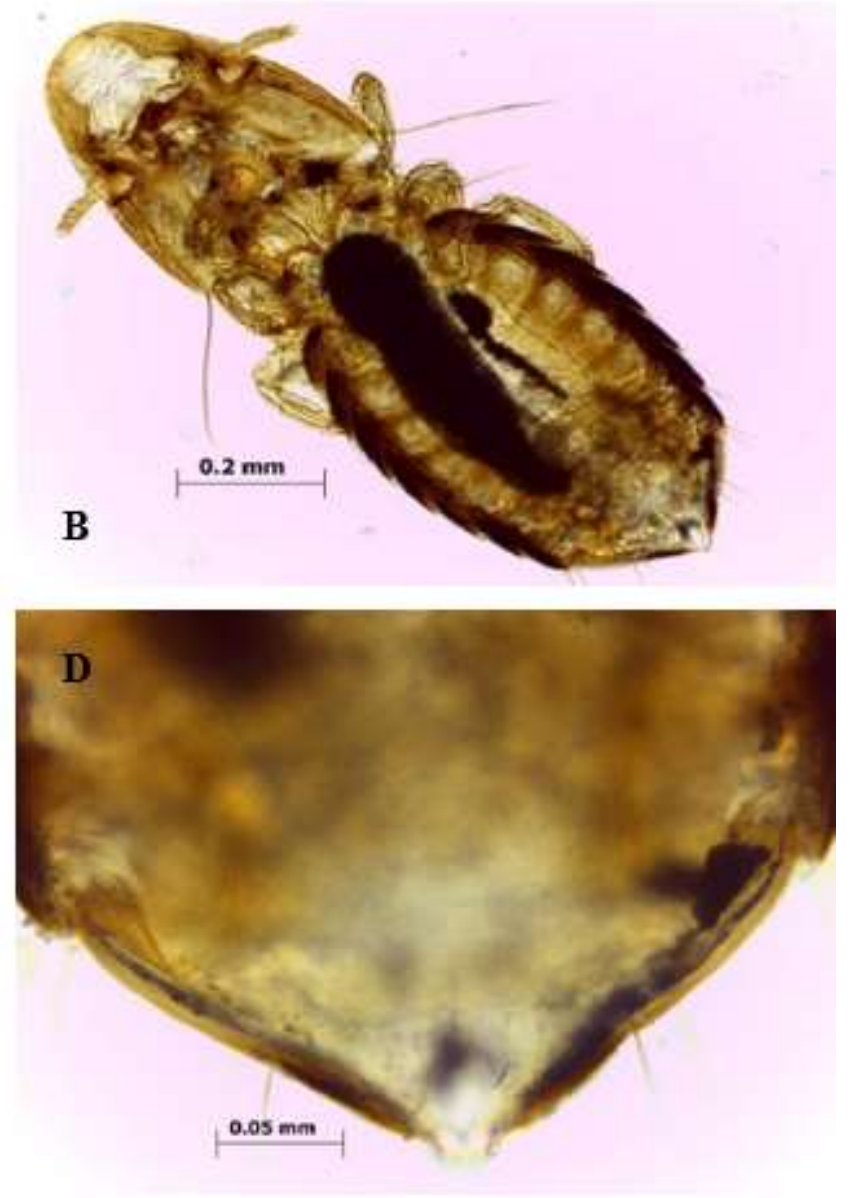

Figure 5: (A) Rallicola fulicae showed adult male, 100x. (B) Adult female, 100x. (C) Male genitalia, 400x. (D) Female posterior end, 400x. 

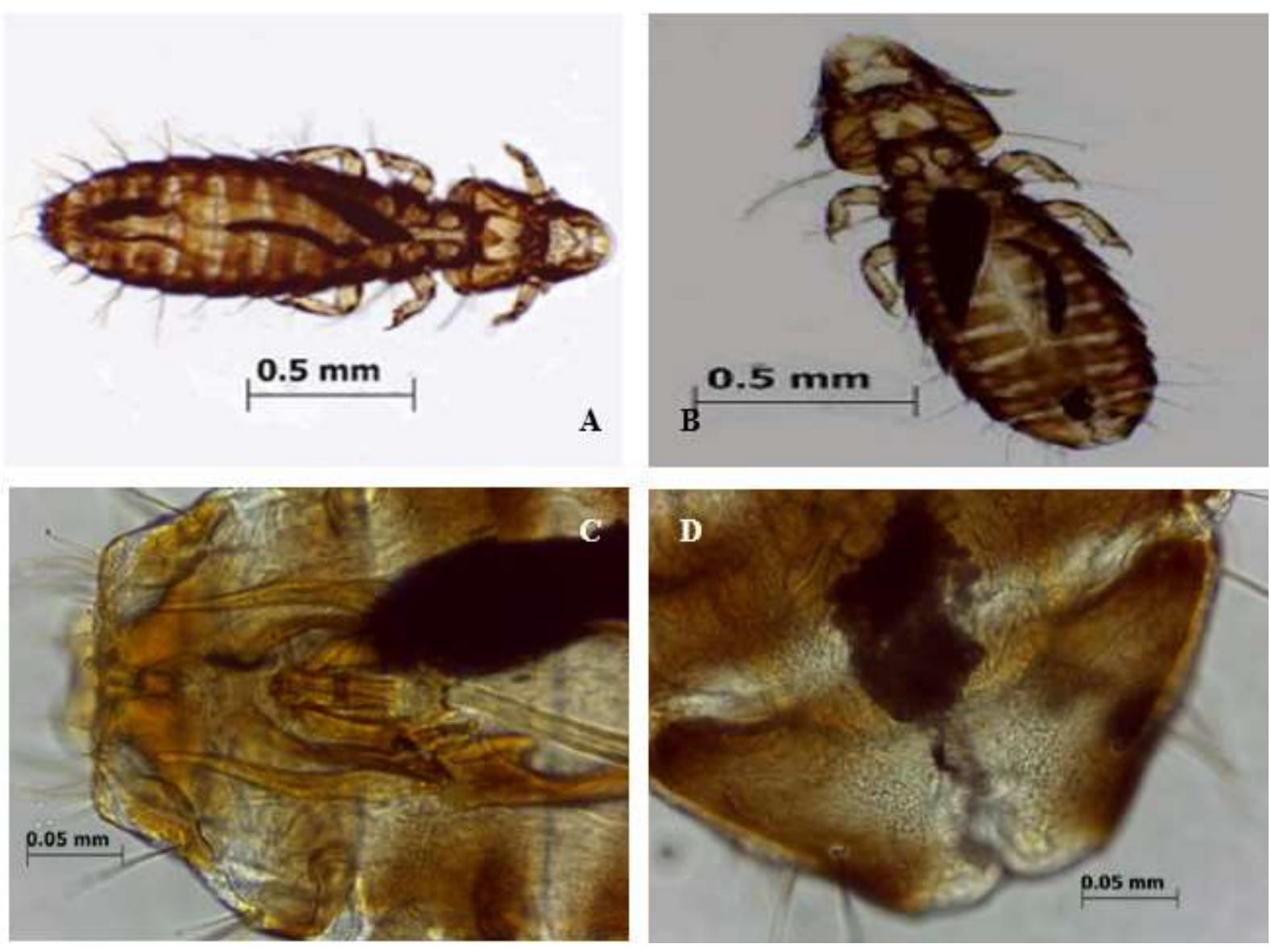

Figure 6: (A) Rallicola fulicae showed adult male, 40x. (B) Adult female, 40x. (C) Male genitalia, 400x. (D) Female posterior end, 400x.

\section{Discussion}

About 10,711 bird species have been detected in the world (19). The birds in Iraq were very numerous and comprise as many as 385 different species. Among these birds many species of aquatic birds could form an important source of animal protein which can be easily available to marsh people and villagers (20).

The birds infested with different species of ectoparasites which live on skin or feathers permanently or temporary (1). Chewing lice (Phthiraptera: Ishnocera, Amblycera) are obligate ectoparasites, which in general parasitize avian species (4), they had severe effect on birds when they present in large numbers, they can cause feather damage, decrease food consumption, loss body weight, egg production, irritation, restlessness and they can effect on birds indirectly by serving as vector or intermediate hosts of other pathogens as bacteria, viruses, fungi and some helminths (1).

The studies on chewing lice of aquatic birds in Iraq are very limited, therefore the studies on the lice have a big potential for new discoveries to investigate and identify louse species on aquatic birds and provide data on the chewing lice list. Mohammad (8) recorded Laemobothrion atrum on F. atra birds, Ciconiphilus decimfasciatus on three aquatic bird species Egretta garzetta, Bubulcus ibis and Ardeola ralloides, Pseudomenopon pilosum lice on F. atra and G. chloropus birds, Ibidoecus bisignatus lice on Plegadis falcinellus birds, Fulicoffula gallinule lice on $G$. chloropus birds, Fulicoffula lurida lice on F. atra birds, Saemundssonia lari lice on three aquatic bird species: $L$. genei, Larus ichthyaetus and Larus ridibundus, Ardeicola rhaphidius lice on P. falcinellus birds, Ardeicola goisagi lice on Nycticorax nycticorax birds, Quadraceps punctatus punctatus lice on three aquatic bird species L. genei, $L$. ichthyaetus and L. ridibundus, Anaticola crassicornis and Anatoecus icterodes lice on Anas clypeata birds.

Four different species of chewing lice related to Menoponidae family have been recorded from Iraq for the first time A. piceus lari isolated from $L$. genei birds, $A$. himantopi and Austromenopon himantopi infested $H$. himantopus birds, Colpocephalum leptopygos isolated from P. falcinellus birds (9). 
Piagetiella titan isolated from the oral cavity of white pelican Pelecanus onocrotalus by Mohammad (10). Three species of chewing lice were recorded for the first time in Iraq during the current study including: Pectinopygus forficulatus on White Pelican P. onocrotalus, Rallicola fulicae on $\operatorname{coot} F$. atra and Rallicola parani on moorhen $G$. chloropus.

In Iraq $P$. titan lice were isolated from buccal cavity of white pelican by Mohammad (10) and in the present study $P$. titan lice were isolated from buccal cavity and $P$. forficulatus isolated from feathers of the same host. Piagetiella titan, are the most common lice species on great white pelican and these two species ( $P$. titan and P. forficulatus) have been reported on great white pelican previously in Turkey (21) and $P$. forficulatus reported on feathers of white pelican by Dik and Uslu (22-23). The measurements of $P$. forficulatus males agreed with other studies as Dik and Uslu (22).

In the current study two species related to the genus Rallicola were isolated, Harrison (24) revealed that the genus Rallicola was small to moderate lice in size and had characteristic genitalia with straight (rarely curved) divergent parameres had two small lobes at their bases and a solid median portion, this genus was confined to the Rallidae and it found upon all genera from the large forms such as Fulica, Prophyrio, Aramus and Ocydromus down to small species of Rallus and Porzana.

Rekasi (25) and Vas et al (26) reported that the R. fulicae infested $F$. atra in Hungary. This lice species isolated in Romania from $F$. atra by Rekasi and Kiss (27-29) and from both $F$. atra and $F$. cristata (Gruiformes: Rallidae) by $R$. fulicae recorded in F. atra in Turkey by Dik et al (2), Western Australia by Stranger and Palma (30), Denmark by Palma and Jensen (31). Rekasi and Kiss (27) reported that the Rallicola minutus infested G. chloropus in Romania, while (26) reported that the R. parani infested G. chloropus in Hungary.

\section{Conclusion}

In Iraq further investigations of Phthiraptera fauna are very important, not only to complete the list, but also to provide information about parasite-host vector relationships and phylogenetic relation among species.

\section{Acknowledgements}

The author thanks Dr. Bilal Dik from Selcuk University of Turkey for help about the confirmation of the identification of some lice species in current study.

\section{References}

1. Johnson KP, Clayton DH. The biology, ecology, and evolution of chewing lice. Illinois Nat His Sur Spe Pub. 2003;24:501. https://www.researchgate.net/publication/50520355 Biology ecology and_evolution_of_chewing_lice

2. $\quad \bar{D}$ ik $\bar{B}$, Yamac $\bar{E} E$, Uslu U. Chewing lice (Phthiraptera) found on wild birds in Turkey. Kafkas Univ Vet Fak Derg. 2011;17(5):787-794. https://www.researchgate.net/publication/281594662_Chewing_lice_P hthiraptera_Found_on_Wild_Birds_in_Turkey

3. Vas Z, Csorgo T, Moller AP, Rozsa L. The feather holes on the barn swallow Hirundo rustica and other small passerines are probably caused by Brueelia spp. lice. J Parasitol. 2008;94:1438-1440. https://www.ncbi.nlm.nih.gov/pubmed/18576840

4. Price RD, Hellenthal RA, Palma RL, Johnson KP, Cayton DH. The chewing lice: World checklist and biological overview. Illinois Nat History Sur. 2003;24:1-48. http://phthiraptera.info/content/chewinglice-world-checklist-and-biological-overview-0

5. Al-Saffar TM, Al-Mawla ED. Some hematological changes in chickens infected with ectoparasites in Mosul. Iraqi J Vet Sci. 2008;22:95-100. DOI: $10.33899 /$ ijvs.2008.5726

6. Rahemo ZI, Al-Dabbagh FA. Recording of chewing louse Philopterus sp. (Mallophaga: Ischnocera) from Crow in Iraq. J Raf Sci. 2009;20:3238. https://www.iasj.net/iasj?func $=$ fulltext\&aId $=39947$

7. Hasan $\mathrm{MH}$, Detection of ectoparasites in different birds, Iraqi $\mathbf{J}$ vet Sci. 2019; 33(2): 37-41. DOI: 10.33899/ijvs.2019.162896

8. Mohammad ZA. Ectoparasites and helminths of some aquatic birds in Al-Sanaf Marsh, Southern Thi-Qar province, Iraq [PhD dissertation] Basra: College of Education of Pure Sciences, University of Basra; 2014. $218 \mathrm{p}$.

9. Mohammad ZA. New records of four chewing lice species related to family: Menoponidae (Mjoberg, 1910) infested some aquatic birds collected from Al-Sanaf marsh, Southern Thi-Qar province, Iraq. World J Pharmaceut Res. 2015;4(7):52-60. http://phthiraptera. info/node/94256

10. Mohammad ZA. New record of chewing lice Piagetiella titan (Menoponidae: Mallophaga) isolated from buccal cavity of white pelican Pelecanus onocrotalus in Thi-Qar province-Southern Iraq. J Thi-Qar Sci. 2015;5(3):27-31. https://jsci.utq.edu.iq/index.php/ main/article/view/146

11. Margolis L, Esch GW, Holmes JC, Kuris AM, Schad GA. The use of ecological terms in parasitology. J Parasitol. 1982;68:131-133. DOI: $10.2307 / 3281335$

12. Thompson GB. Notes on species of the genus Pectinopygus (s.1.). (Mallophaga) II. Ann Mag Nat Hist. 1940;11(5):429-432.

13. Thompson GB. Notes on species of the genus Pectinopygus (s.1.). (Mallophaga) III. Ann Mag Nat Hist. 1946;11(13):767-780

14. Thompson GB. Notes on species of the genus Pectinopygus (s.1.). (Mallophaga) IV. Ann Mag Nat Hist. 1947;11(14):317-327.

15. Thompson GB. Notes on species of the genus Pectinopygus (s.1.). (Mallophaga) V. Ann Mag Nat Hist. 1948;11(14):346-352.

16. Clay T. Revisions of the genera of Mallophaga. I. The Rallicola complex. Proc Zool Soc Lond. 1953;123:563-587.

17. Clay T. A key to the genera of the Menoponidae (Amblycera: Mallophaga: Insecta). Entomol. 1969;24:3-26.

18. Emerson KC. A review of the genus Rallicola (Philopteridae, Mallophaga) found on Aramidae, Psophiidae and Rallidae. Ann Entomol Soc Am. 1955;48:284-299.

19. Gill F, Donsker D. IOC world bird list. Available at http://www.worldbirdnames.org. 2018.

20. Mahdi N, and Georg PV. A systematic list of the vertebrates of Iraq. Iraqi Nat Hist Mus. 1969;26:1-104.

21. Dik B, Hugul F, Ceylan O. Chewing lice (Phthiraptera: Amblycera, Ischnocera) of some aquatic birds in Konya province, Turkey, new records for Turkish fauna. Ankara Üniv Vet Fak Derg. 2017;64:307312.

https://www.researchgate.net/publication/319903961_Chewing_lice_P hthiraptera_Amblycera_Ischnocera_of_some_aquatic_birds_in_Kony a_province_Turkey_new_records_for_Turkish_fauna

22. Dik B, Uslu U. Mallophaga species observed in white pelicans (Pelecanus onocrotalus, Linnaeus) in Turkey. Türkiye Parazitoloji 
Dergisi. 2008;32(1):71-76. https://www.researchgate.net/publication/ 5499973_Mallophaga_species_observed_in_white_pelicans_Pelecanu s_onocrotalus_Linnaeus_in_Turkey

23. Dik B, Uslu U.Ectoparasites of hares (Lepus europaeus Pallas) in Konya Province. Turkish J Vet Ani Sic. 2018; 42: 65-72. DOI: Google Scholar BibTexRTF MARC XML RIS 94376.pdf

24. Harrison L. Mallophaga from Apteryx and their significance with a note on the genus Rallicola. Parasitol. 1915;8(1):88-100.

25. Rekasi J. Bird lice (Mallophaga) parasitizing the birds of Hungary. Aquila J. 1993;100:71-93. http://phthiraptera.info/content/bird-licemallophaga-parasiting-birds-hungary

26. Vas Z, Rekasi J, Rozsa L. A checklist of lice of Hungary (Insecta: Phthiraptera). Ann His Nat Mus Nat Hung. 2012;104:5-109. https://www.researchgate.net/publication/235826612_A_checklist_of_ lice_Insecta_Phthiraptera_of_Hungary

27. Rekasi J, Kiss JB. Weitere Angaben zur Kenntnis der Federlinge. Mallophaga Rumanien. J Para Hung. 1984;97-117. https://www.researchgate.net/publication/266402914_Weitere Angab en_zur_Kenntnis_der_Federlinge_Mallophaga_Rumanien_der_Vogel _Nord-Dobrudschas_II_II
28. Rekasi J, Kiss JB. Data on the bird lice (Mallophaga) of some bird species from the Danube Delta (North Dobrogea, Romania). Travaux Mus Nat His Nat. 1997;39:59-82. https://www.researchgate.net/ publication/262493839_DATA_ON_THE_BIRD_LICE_MALLOPH AGA_OF_SOME_BIRD_SPECIES_FROM_THE_DANUBE_DELT A_NORTH_DOBROGEA_ROMANIA

29. Rekasi J, Kiss JB. New data on the lice (Phthiraptera) of some birds in northern Dobrogea (Romania). Acrocephalus. 2006;27 (131):139-145. https://www.researchgate.net/publication/266280288_New_data_on_t he_lice_Phthiraptera_of_some_birds_in_Northern_Dobrogea_Romani a

30. Stranger HR, Palma RL. Lice (Insecta: Phthiraptera) from some Australian birds. Rec West Australian Mus. 1998;19:169-186. https://www.researchgate.net/publication/283018213_Lice_Insecta_P hthiraptera_from_some_Australian_birds

31. Palma RL, Jensen JK. Lice (Insecta: Phthiraptera) and their host associations in the Faroe Islands. Steenstrupia Copenhagen Denmark. 2005;29(1):49-73.

https://www.researchgate.net/publication/228656433_Lice_Insecta_P hthiraptera_and_their_host_associations_in_the_Faroe_Islands 